\title{
薄型光ディスク装置用傾き補正三次元アクチュエータの開発*
}

\author{
木 村 勝 彦*1, 小笠原浩*2 \\ 佐 竹 光 雄*2, 伊 東 徹 雄*3

\section{Development of a Three-Dimensional Actuator for Compensating Disc Tilt in Slim Optical Disc Drives} \\ Katsuhiko KIMURA*4, Hiroshi OGASAWARA, \\ Mitsuo SATAKE and Tetsuo ITO \\ ${ }^{* 4}$ Mechanical Engineering Research Laboratory, Hitachi, Ltd., \\ 502 Kandatsu, Tsuchiura-shi, Ibaraki, 300-0013 Japan

\begin{abstract}
A three-dimensional actuator for compensating disc tilt in slim optical disc drives was developed. The actuator inclines the objective lens according to the disc tilt in addition to the focus and track-driving directions. The moving part of the actuator has three driving coils and supported by six suspension bars. Its moving coil structure has the advantage to increase the driving sensitivity. The measured driving sensitivities in the focus, track and tilt directions were $104,106 \mathrm{~m} / \mathrm{s}^{2} / \mathrm{V}$ and $1.7^{\circ} \mathrm{V}$, respectively. These values are enough for high-speed read-write operation. The result on disc tilt compensation verified the effect of this actuator that the jitter of DVD read-out signal with tilt control was within $10 \%$ at $1.0^{\circ}$ disc radial tilt.
\end{abstract}

Key Words: Information Processing Equipment, Optical Instrument, Electromagnetic Actuator, Vibration of Mechanism, Optical Disc Drive, Disc Tilt, Magnetic Circuit

\section{1. 粕 吾}

コンピュータの外部記憶装置である光ディスク装置 は，CD-ROMやDVD-ROMティスクの再生に加え て, CD-R/RWやDVD-R/RW/RAMなE゙のディスク へ記録できる装置への要求が拡大している.

光ディス装置は，レーザ光を対物レンズによりデ イスク記録面上に直径約 $1 \mu \mathrm{m}$ のスポットに集光し情 報の記録再生を行う.ささまざまなディスクに対して記 録再生を行う上での課題の一つとして, ディスクと対 物レンズ間の傾きの低減が挙げられる. 対物レンズで 集光された光は，ディスクの透明基板を通過して記録 面に焦点を結ぶ.このとき対物レンズとディスクが相 対的に傾くと，ディスク記録面上で集光スポットが広 がり，記録再生性能が低下する。

この傾きによる影響を補正する方法として，これま でに 2枚の非球面レンズを移動させる方法 ${ }^{(1)}$, 液晶板 を用いる方法 ${ }^{(2)}$ ，対物レンズを従来のフォーカス方向 とトラック方向の並進駆動に加えて傾き方向のチルト

\footnotetext{
* 原稿受付 2003 年 10 月 8 日.

*1 正員, (株) 日立製作所機械研究所( $300-0013$ 土浦市神立 町 502).

*2 (株) 日立メディアエレクトロニクス(-244-0817 横浜市户 塚区吉田町 501)

*3 (株) 日立アドバンストデジタル（画244-0817 横浜市戸塚区 吉田町 292).

E-mail : anton $@$ gm.merl.hitachi.co.jp
}

駆動も行う対物レンズアクチュエータを用いる方法 ${ }^{(3)}$ 〜(5な゙が報告されている.このうち対物レンズを三 方向に駆動する三次元アクチュエー夕は, 従来の装置 構造からの変更点が少ないことから, 有望な傾き補正 方法と考えられる.

本報告はこの三次元アクチュエータを装置高さ $12.7 \mathrm{~mm}$ の薄型装置用に開発することを目的とし，薄 型でチルト駆動可能なアクチュエータの構造と特性に ついて述べる.

\section{2. 三次元アクチュエータ㯵造}

2.1 開発目標とアクチュエー夕構造 対物レン ズアクチュエータは，対物レンズの焦点位置をディス ク記録面上の目標トラックに位置決めする機構である. 図 1 に示す例において，対物レンズの焦点方向がフォ 一カス方向, ディスクの半径方向がトラック方向, デ ィスクの半径方向に傾く方向がチルト方向となる.

対物レンズアクチュエータは, 高速記録再生を行う 上で高速に回転するディスクに追従できる高い駆動感 度と, 広帯域な制御系を実現する振動特性が求められ る(6) ().

対応する装置の記録再生速度の仕様である CD24倍 速およびDVD8倍速から決定したアクチュエータの 開発目標を表 1 に示す. 


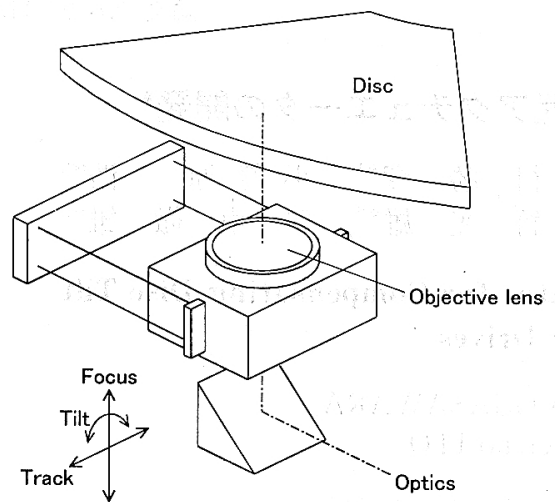

Fig. 1 Objective lens actuator

アクチュエータの高さは薄型装置用として標準的な 6.0mmとした.

フォーカス方向とトラック方向の駆動感度の目標值 は, 印加電圧に対する発生加速度を表す加速度感度と して $80 \mathrm{~m} / \mathrm{s}^{2} / \mathrm{N}$ 以上とした. ディスク回転周波数は CD24倍速時が 90Hz，DVD8 倍速時が $80 \mathrm{~Hz}$ であり，面 振れと偏心の外乱加速度は CD24倍速時のほうが大き くなる. 上記の目標值 $80 \mathrm{~m} / \mathrm{s}^{2} / \mathrm{V}$ は, 駆動コイルへ $1 \mathrm{~V}$ を入力したときにディスク回転周波数 $90 \mathrm{~Hz}$ で $0.25 \mathrm{~mm}$ の面振れ・偏心に追従できることを表している.

チルト補正は, ディスクが有する反りやディスクを 交換したときに生じる取り付け傾きに対する静的な補 正を想定し，チルト方向の駆動感度の目標值は，静的 な駆動感度として $1.5^{\circ} \mathrm{N}$ 以上とした。 これはチルト コイルの抵抗を $4 \Omega$ とした場合に, $1^{\circ}$ チルトさせた ときの消費電力が $0.1 \mathrm{~W}$ 以下となる条件から設定した.

以上の目標に対して考案したアクチュエー夕構造を 図2に示す.また図3に駆動コイルと磁石の配置およ ひ駆動力の方向を示す。

本アクチュエータは対物レンズをホルダ上面の中央 に配置するレンズセンター構造となっている.フォー カスコイルおよびチルトコイルは2個一連とし，トラ ック方向において対物レンズの両側に分けて配置する. 2個のチルトコイルの巻線方向を反対にすることで, それぞれ逆向きの力を発生させ，対物レンズを傾かせ るモ一メントを発生させる. トラックコイルは 4個一 連としてホルダの側面に固定する.

対物レンズとホルダおよび駆動コイルからなる可動 部を固定部に対して支持するサスペンションは，各駆 動コイルへの電流供給を兼ねている. サスペンション の本数は6本とし, 各駆動コイルへ独立に駆動電流を 供給する.

磁石は可動部を挟んで4個使用している. トラック
Table 1 Target specifications

\begin{tabular}{|c|c|c|}
\hline \multicolumn{2}{|c|}{ Actuator height } & $6.0 \mathrm{~mm}$ \\
\hline \multirow{3}{*}{ Driving sensitivity } & Focus & $80 \mathrm{~m} / \mathrm{s}^{2} / \mathrm{V}$ \\
\cline { 2 - 3 } & Track & $80 \mathrm{~m} / \mathrm{s}^{2} / \mathrm{V}$ \\
\cline { 2 - 3 } & Tilt & $1.5 \% / \mathrm{V}$ \\
\hline
\end{tabular}

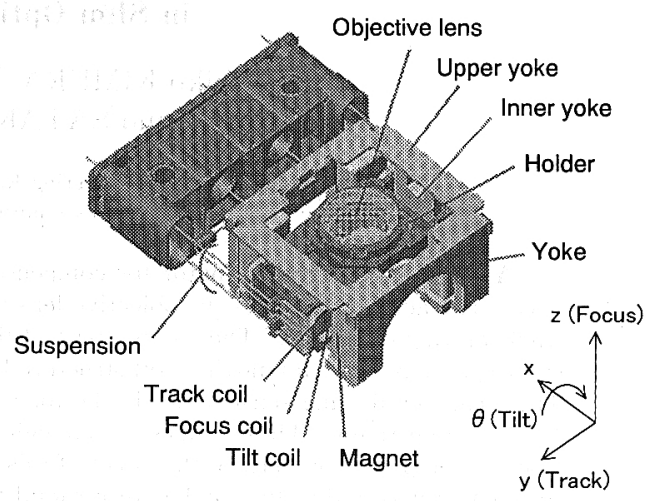

Fig. 2 Configuration of slim three-dimensional actuator

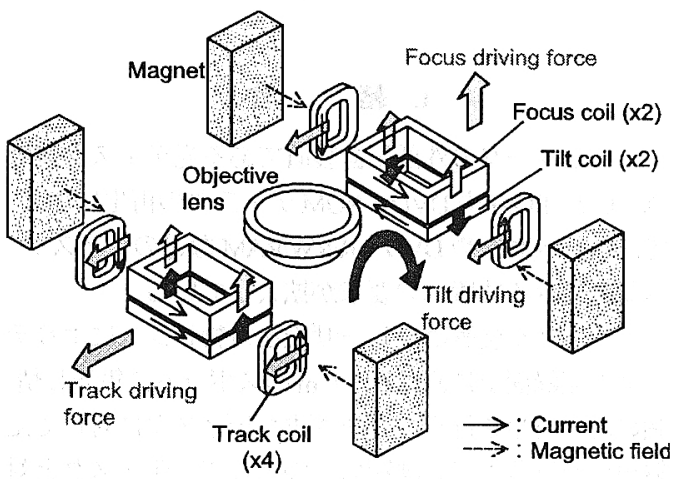

Fig. 3 Driving coils and forces in three directions

方向に沿って 2 個の磁石を間隔を空けて配置すること， およびフォーカスコイルおよびチルトコイルを対物レ ンズの両側に分けて配置することで, 光学系からの光 路を確保しつつ薄型化を図っている.

本アクチュエータの特徵は次の三点である.

一つは, フォーカス, トラック, チルトの三系統す ベてで駆動コイル側が動作するムービングコイル方式 としていることである. これにより，従来の二次元ア クチュエータと同じ構成で, チルト駆動機能を付与す ることが可能である. 磁石を可動部側に有するムービ ングマグネット方式に対して，ムービングコイル方式 は可動部質量を軽く構成できるので, 駆動感度の点で 有利となる。 
他の二点は可動部の振動モードと駆動力作用位置の 最適化により振動低減を図っている( ${ }^{(8)}$ (10) ことである. その一つは, 応答点である対物レンズをホルダ上面の 中央に配置することで, ピッチングやヨーイングと呼 ばれる可動部の回転振動と, ねじれ振動に対して, 対 物レンズ位置を変形の中心に近づけ, 応答振幅の低減 を図っている.

もう一つは, 可動部の弾性変形である高次振動の応 答振幅の低減である. 薄型装置用のアクチュエータで は高次振動が 10kHz 30kHz で生じ, 制御系で問題と なる場合がある. 本アクチュエータではフォーカス方 向に約 $13 \mathrm{kHz}$ で生じる可動部の曲け振動に対して, そ の節にフォーカス方向の駆動力を作用させる磁石位置 とすることで, 高次振動の低減を図っている.

\section{2 チルト駆動機構の設計 傾き方向へのチル} 卜動作はサスペンションの軸回り（図 2 の $\mathrm{x}$ 軸回り） の回転動作であり, 変形の中心はサスペンションの取 り付け位置の中心となる.

図 4 にチルト動作時のサスペンションの変形状態を 示す. サスペンションの支持中心の回りに作用するモ 一メントを $M$, 各サスペンションに作用する力を $F$, 各サスペンションの変位量を $d$, 支持中心から 各サスペンションまでの取り付け長を $L$, サスペン ションのばね定数を $k$, サスペンションの数を $n$, チルト角を $\theta$ とすると,

$$
\begin{aligned}
& \theta=\frac{d}{L} \\
& F=k d \\
& M=n F L
\end{aligned}
$$

である. 式(1)〜(3)から

$$
\theta=\frac{M}{n k L^{2}}
$$

となる. また, チルト角 $\theta$ は回転のばね定数を $K_{\theta}$ と すると,

$$
\theta=\frac{M}{K_{\theta}}
$$

と表されるので, 回転のばね定数 $K_{\theta}$ は

$$
K_{\theta}=n k L^{2}
$$

となる.

また, モーメント $M$ はチルト駆動力 $F_{t i l t}$ と, チル 卜駆動力の作用距離 $D$ により,

$$
M=F_{\text {tilt }} D
$$

と表される.

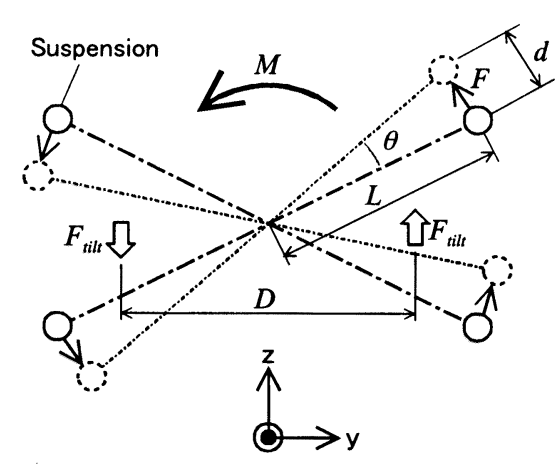

Fig. 4 Rotating deformation of suspensions

チルト方向の駆動感度 $S_{\text {tilt }}$ は, チルトコイルへの 印加電圧 $V_{\text {tilt }}$ に対するチルト角で表され,

$$
S_{\text {tilt }}=\frac{\theta}{V_{\text {tilt }}}=\frac{M}{V_{\text {tilt }} K_{\theta}}=\frac{F_{\text {tilt }} D}{V_{\text {tilt }} K_{\theta}}
$$

となる.

したがって, チルト方の駆動感度 $S_{\text {tilt }}$ を大きく するには, チルト駆動力を大きくする他に, その作用 距離 $D$ を大きくとること, および回転のばね定数 $K_{\theta}$ を小さくすることが有効である.

しかし, 回転のばね定数を小さくしすぎると, 外乱 が加わったときに傾きやすくなるので, 適切な設計が 必要である.

チルト方向の固有振動数（以下ローリング周波数と 記す） $f_{r}$ は，回転のばね定数 $K_{\theta}$ と可動部の $\mathrm{x}$ 軸回 り慣性モーメント $I_{G}$ により,

$$
f_{r}=\frac{1}{2 \pi} \sqrt{\frac{K_{\theta}}{I_{G}}}
$$

と表される. 可動部の $\mathrm{x}$ 軸回り慣性モーメント $I_{G}$ は, 可動部質量 $\boldsymbol{m}$ と代表半径 $\boldsymbol{r}$ により,

$$
I_{G}=m r^{2}
$$

と表すことができる.

一般にローリング周波数 $f_{r}$ は $100 \mathrm{~Hz} \sim 200 \mathrm{~Hz}$ になる 場合が多く, ディスク回転周波数と一致もしくは近い 場合には, 共振現象を示しチルト角が増大する.

フォーカス制御やトラック制御と同様に, チルト補 正も動的にフィードバック制御を行う場合は, このロ ーリング共振を抑圧することが可能である. しかし, ここではディスク自体が有する反りやディスクを交換 したときに生じる取り付け傾きに対する静的なチルト 補正を想定しているので, ローリング共振の影響を把 握しておく必要がある. 
ローリング共振は, フォーカス方向あるいはトラッ ク方向の駆動力が可動部の重心からずれて作用した場 合に生じる. CD と DVDではディスクの基板厚が異 なることから, また装置の組立誤差を考えると, 可動 部がフォーカス方向に変位することは避けられず，こ の状態でトラック方向の駆動力が作用した場合にロー リング共振が生じる.

トラック方向偏心量 $\Delta T R$ を周波数 $f$ で駆動する ときのトラック方向の駆動力 $F_{t r}$ は,

$$
F_{t r}=m \Delta T R(2 \pi f)^{2}
$$

となる. フォーカス方向の変位量を $\triangle A F$ とすると, $F_{t r} \times \Delta A F$ が可動部に作用するモーメントとなる.

したがって, 周波数 $f$ に対するチルト角 $\theta(f)$ は, 減衰比を $\zeta$ として一自由度振動系の応答として表す と,

$$
\theta(f)=\frac{F_{t r} \Delta A F}{K_{\theta} \sqrt{\left(1-\frac{f^{2}}{f_{r}^{2}}\right)^{2}+\left(2 \xi \frac{f}{f_{r}}\right)^{2}}}
$$

となる.

並進方向の固有振動数 $f_{0}$ は

$$
f_{0}=\frac{1}{2 \pi} \sqrt{\frac{n k}{m}}
$$

であるから，式(12)は式（6)(11）(13)を用いて

$$
\theta(f)=\frac{f^{2} \Delta A F \Delta T R}{L^{2} f_{0}^{2} \sqrt{\left(1-\frac{f^{2}}{f_{r}^{2}}\right)^{2}+\left(2 \xi \frac{f}{f_{r}}\right)^{2}}}
$$

となる. また，ローリング周波数 $f_{r}$ と並進方向の固 有振動数 $f_{0}$ の関係は, 式(6) (9) (10) (13)から

$$
f_{r}=\frac{L}{r} f_{0}
$$

となり, $f_{r}$ は $f_{0}$ の $(L / r)$ 倍と表される.

ローリング共振のチルト角を低減するには式

(14) (15)からサスペンション取り付け長 $L$ を大きく, 可動部の代表半径 $r$ を小さくすれば良い. しかし，可 動部の代表半径 $r$ を小さくすることはチルト駆動力の 作用距離 $D$ も小さくなるので, 先のチルト駆動感度 を高める指針と相反することになる.
本アクチュエータではローリング共振を避けること を優先させ, ローリング周波数 $f_{r}$ をディスク回転周 波数よりも高く設定する.

式(14)において周波数 $f$ を対応すべきディスク回 転周波数の上限の $90 \mathrm{~Hz}$ とし， ローリング周波数 $f_{r}$ に 対するチルト角 $\theta$ を計算した結果を図 5 に示す．パラ メー夕は, $\Delta A F=0.3 \mathrm{~mm}, \Delta T R=0.1 \mathrm{~mm}, \zeta=0.1$, $L=6.0 \mathrm{~mm}, r=3.3 \mathrm{~mm}$ とした. サスペンションの取 り付け長 $L$ は装置寸法内で可能な範囲で大きくした. チルト角の許容值を $0.2^{\circ}$ とすると，これを満たす ローリング周波数 $f_{r}$ は $120 \mathrm{~Hz}$ 以上, $f_{0}$ は $67 \mathrm{~Hz}$ 以上 となる. したがって本アクチュエータでは $f_{0}$ を $70 \mathrm{~Hz}$ に設定した.

この条件において, 駆動感度を向上するには可動部 質量の軽量化が重要となる.

$f_{0}$ を一定として可動部質量を軽くすると, サスペ ンションのばね定数が小さくなるので静的なチルト駆 動感度を向上することができる.

また, 可動部質量を軽くすることはフォーカス方向 とトラック方の加速度感度の向上にもつながる. 本 アクチュエータはムービングコイル方式とすることで, 可動部質量の軽量化を図っている.

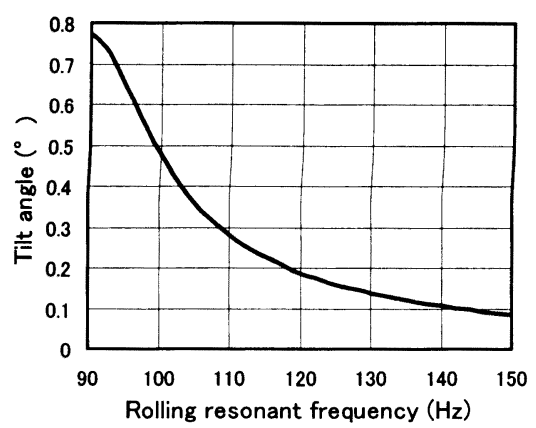

Fig. 5 Calculated tilt angle to rolling resonant frequency

\section{3. 非牞特性の計箱結果}

フォーカス方向とトラック方向の振動特性の計算結 果を図 6 に示す. フォーカス方向の $13 \mathrm{kHz}$ に可動部の 曲げモードが存在する．この曲げモードの節にフォー カス駆動力を作用させる磁石位置とすることで，振幅 をほぼゼロに抑制している. トラック方向の約 $30 \mathrm{kHz}$ に存在する高次振動は, 可動部のトラック方向両端の 側面の変形モードである. そのピークゲインはゲイン カーブ上の $20 \mathrm{kHz}$ におけるゲインと同程度であり, DVD8倍速時の制御系として, ゲインクロス周波数が 
$6 \mathrm{kHz}$, 位相クロス周波数が $15 \mathrm{kHz}$ 程度で, ゲイン余裕 が 10dB程度の制御系を構成することができる.

三次元磁場解析により各コイルで発生する駆動力を 求め, 可動部質量の計算值 $0.16 \mathrm{~g}$ から, 各方向の駆動 感度を計算した. その結果, 加速度感度はフォーカス 方向が $107 \mathrm{~m} / \mathrm{s}^{2} / \mathrm{N}$, トラック方向が $109 \mathrm{~m} / \mathrm{s}^{2} / \mathrm{N}$, チルト 駆動感度は $1.9^{\circ} \mathrm{N}$ となり, 目標を満たす值となって いる.
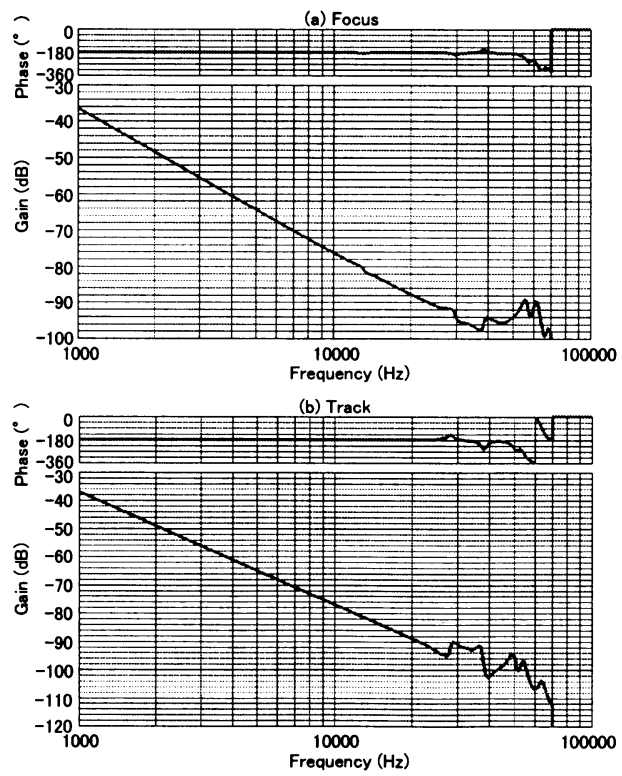

Fig. 6 Calculated frequency response characteristics

\section{4. 实苚拮果}

前章の計算結果に従い, 薄型三次元アクチュエータ を製作し，駆動特性とチルト補正の実験を行った.

4.1 睎動特性 アクチュエータの周波数応答特 性の測定結果を図 7に示す. 各コイルへの印加電流に 対するフォーカス方向の変位応答を(a)に，トラック 方向の変位応答を(b)に, チルト方向の角度応答を (c) に示す.

フォーカス方向は $70 \mathrm{~Hz}$ にサスペンション支持系の 一次共振があり, $13 \mathrm{kHz}$ に可動部の曲げ振動が生じて いる. $13 \mathrm{kHz}$ の振動は, ゲインカーブ上での振幅の変 化が 2dBであり, 計算值より若干大きいもののピー クとしては実用上問題無いレベルである. トラック方 向は測定した $50 \mathrm{kHz}$ までの範囲において位置決め制御 系で問題となる振動は無く良好な特性が得られている. チルト方向のローリング周波数は設計值通り $120 \mathrm{~Hz}$ と なっている.
各方向の駆動感度を表 2 に示す. フォーカス方向と トラック方向の加速度感度は, 図 7 の印加電流に対す るゲインを表 2 に示すコイル抵抗で除算して電圧に対 する加速度感度として示す. チルト方向の静的感度を 含めていずれも計算值と同等で目標を満足する CD24 倍速・DVD8 倍速の記録再生に対応可能な值が得られ た.

(a) Focus

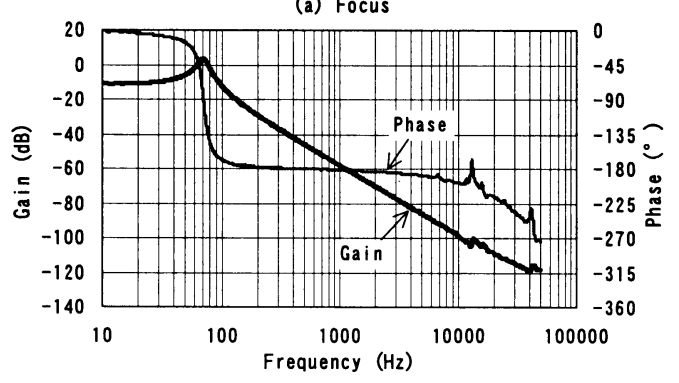

(b) Track

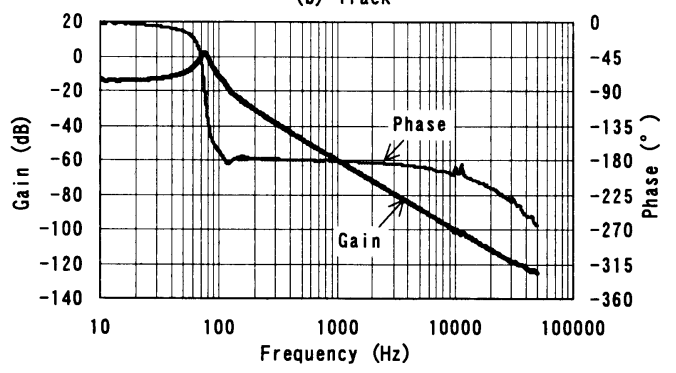

(c) Tilt



Fig. 7 Frequency response of new actuator

Table 2 Experimental results on driving performance

\begin{tabular}{|c|c|c|}
\hline \multicolumn{2}{|c|}{ Mass of moving part } & $0.166 \mathrm{~g}$ \\
\hline \multirow{3}{*}{ Driving sensitivity } & Focus & $104 \mathrm{~m} / \mathrm{s}^{2} / \mathrm{V}$ \\
\cline { 2 - 3 } & Track & $106 \mathrm{~m} / \mathrm{s}^{2} / \mathrm{V}$ \\
\cline { 2 - 3 } & Tilt & $1.7^{\circ} / \mathrm{V}$ \\
\hline \multirow{3}{*}{ Coil resistance } & Focus & $5.0 \Omega$ \\
\cline { 2 - 3 } & Track & $4.1 \Omega$ \\
\cline { 2 - 3 } & Tilt & $4.2 \Omega$ \\
\hline
\end{tabular}




\section{2 チルト補正の効果 チルト補正のプロセス} は次の通りである. 実験結果で得られたチルト駆動感 度から算出した駆動電圧をチルトコイルに印加し, ア クチュエータを $1^{\circ}$ の範囲でチルト駆動させ, その ときの再生信号のジッ夕を計測, 記憶する. ジッ夕は 基準信号の周期に対する検出信号の周期のずれを表し, ディスクが傾くと集光性能が低下しジッタが増加する. したがって, ジッタが最小となる駆動電圧を選択しチ ルトコイルに印加することで, ディスクと対物レンズ の相対傾きを補正することができる.

上記の方法で行ったチルト補正の結果を図 8 に示す. スピンドルモータに傾けて取り付けたディスクの傾き 角を横軸に，DVDーROMディスクを再生したときの ジッ夕を縦軸に示している. 白丸のプロットで示すチ ルト補正を行わない場合は, ディスクの傾き $\pm 1^{\circ}$ に 対してジッタが 20〜30\%となる. ジッ夕の許容值を $15 \%$ とすると, ディスク傾きのマージンは $0.6 \sim 0.7^{\circ}$ となる.

一方, 黒印で示すチルト補正を行った場合は, ディ スクの傾きが $\pm 1^{\circ}$ の場合でもジッ夕は $10 \%$ 以下であ り, ディスクの傾きが無い状態とほぼ同じジッタが得 られた.

なお，図8でチルト補正を行わない場合のジッ夕特 性は，現行の製品レベルを示しており，この状態でも 使用することは可能である. さらに本アクチュエータ を用いて，ディスクが交換される度にディスクの傾き を検出し，その傾きに応じて対物レンズの傾きを設定 することで, ディスクごとに適切なチルト補正を行う ことが可能となる.

以上から, 開発した薄型三次元アクチュエータがデ イスクのチルト補正に有効であることを確認できた.

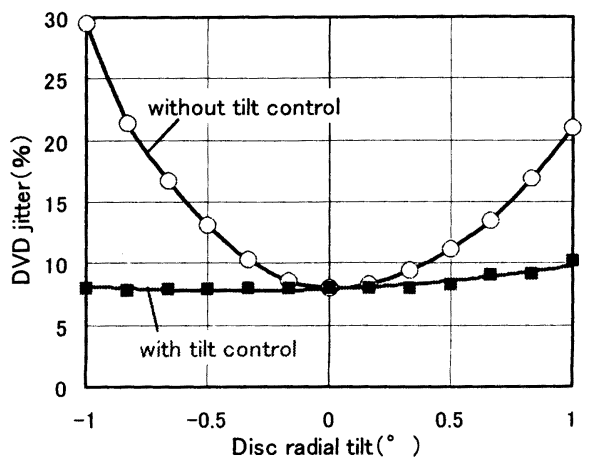

Fig. 8 Results on tilt control
5. 結

薄型光ディスク装置用対物レンズアクチュエータに おいて, 対物レンズをフォーカス, トラック, チルト の三方向に駆動するアクチュエータの開発を行い，以 下の結論を得た.

（1）チルトコイルを対物レンズの両側に分け， 6 本 のサスペンションで支持するアクチュエー夕構造を提 案した.

（2）薄型装置として CD24 倍速・DVD8 倍速の記録再 生に対応できる振動特性と駆動特性を満足した上で, ディスクの傾きに対して, チルト補正により再生信号 ジッタを低減できることを確認した.

\section{文献}

(1) N.Eguchi et al., Fast Disk Skew Servo for Optical Disk Pickup, Symposium on Optical Memory, (1994), 83-84.

（2）立石潔・他 4 名, 液晶によるチルトサーボ，第 58 回応用物理学会講演予稿集, No.3, (1997), 1135.

（3）永里誠・他 3 名, 高密度光ディスク用 4 軸対物 レンズアクチュエータの開発, 機械学会年次大会講演 論文集 V, (1999), 151-152.

（4）井上雅之・他 3 名, DVD-ROM 用光ピックアッ プ, 日立評論, 82-11, (2000), 49-52.

(5) J.Aso et al., High Response Actuator with Tilt Function for $12.7 \mathrm{~mm}$ Slim Optical Disc Drives, ISOM/ODS2002, (2002), 326-328.

（6）木村勝彦 - 他 5 名, 高速 CD-ROM 装置用対物 レンズアクチュエータの開発, 機論, 66-652, C(2000), 179-184.

(7) IH.Choi et al., Concentrated anisorropic magneti-zation for high sensitivity of optical pickup actuator, IEEE Trans. Magn, 35-3, (1999), 1861-1864.

（8）梶原逸朗・他 4 名, 制御性を考慮した構造最適 化法による光サーボ系の設計（第 3 報），機論，55516, C(1989), 2045-2051.

（9）市原順一・他 2 名, 光磁気ディスク装置用トラ ッキング機構, 精密工学会誌, 58-8, (1992), 13931398.

（10）木村勝彦・他 2 名, 薄型 DVD 装置用対物レン ズアクチュエータの開発, 機論, 68-674,C(2002), $116-121$. 